\title{
Adaptation or Loss in News Translation The BBC Arabic and English Websites as an Example \\ By
}

Dr. Taher Mahmoud Okasha*

tahirokkasha@yahoo.com

\section{Abstract}

This paper deals with loss that occurs in news translation when BBC translators render a news story from Arabic into English or vice versa. It shows how some translators fail to deal with the dimension of rendering discourse as a social practice, unintentionally or even intentionally to manipulate the original relations of power and ideology implied in the source text. Light is shed on the circumstances under which the discourse is produced. The research model is highly sociological and culturist. It seeks to uncover the complex social, political, cultural and ideological forces which shape media translation practices. The population under analysis is a group of texts carefully selected to explore the qualitative aspects of the translations. The analyses are done in light of Fairclough's approach to CDA that depends on a method of three components: that is, description, interpretation and explanation. In some cases, critical discourse analysis and corpus linguistics are used together to examine translated texts and produce more general results. Analyses of texts along different periods of time prove that translating news stories on the $\mathrm{BBC}$ websites is for the most part a process of adaptation; editors adapt the story, whether political, scientific, sports or economic, to make it accessible to the reader. Eventually, the study recommends that there is an urgent need for building Arabic translational corpora. Such corpora are to be used with other linguistic and cultural tools within the framework of a multidisciplinary approach to get the best results for any issue in translation studies.

Keywords: news translation, translation theory, corpus linguistics, Fairclough's method.

* Department of English - Faculty of Al Alsun - Aswan University 


\section{Introduction:}

This paper deals with loss that occurs in news translation when BBC translators render a news story from Arabic into English or vice versa. It has been noted that some top stories and news on the BBC Arabic website are translated from the English source or the other way round. The history of this problem goes in my mind back to as early as 1999 when I was a translation diploma student at Cairo University where I used to listen to the BBC English news bulletin on the radio, then listen to the Arabic edition the next hour. The texts selected for this study are from the BBC Arabic and English websites. They are analyzed in light of the three components of Fairclough's method and other translation tools.

\section{Reasons for Choosing the BBC Arabic and English websites:}

BBC news websites are outstanding sources of news. Many people and agencies all over the world depend on the BBC as a reliable source of news. Some translators fail to deal with the dimension of rendering discourse as a social practice, unintentionally or even intentionally to manipulate the original relations of power and ideology implied in the source text. BBC English and Arabic pairs of texts are essential parallel corpora that reflect the reality of the translation profession and have a potential to be used for translational research and pedagogical purposes. Not only BBC translators may benefit from this study, but also other translators working in the field of journalism will find it 
useful especially as far as discourse-as-social-practice is concerned.

\section{Review of the Literature:}

In his A Linguistic Analysis of the Difficulties Faced by Professional Translators in Rendering Problematic Arabic Headlines, Khaled Tawfiq (2014) discusses the problems of rendering headlines. He points out that the problem stems from the fact that headlines present a clear violation of conventional language rules. Losses and violations may also happen for other reasons as indicated by Jeremy Munday (2011):

"when analysing a corpus of articles from Scientific American and their French sister publication Pour la Science, the 'translations' in this kind of publication are often subject to cuts and adaptations for the target audience... The tight translation deadline for the publication will certainly mean that the translators have little time for revision and may therefore adopt a Mini-max, cognitively less demanding 'literal' translation strategy" (182).

What we need is more case studies in the field of news/media translation to "illustrate how translation students might use a parallel corpus as an aid to translation" (Jennifer Pearson: 17). Increasing number of translation training programs obliges us to do more refined studies on real translation problems that would help develop the genre of translation and the heroes and heroines working in the field 
with their own hands. So many books are written on news and media translation, but no study uses the tools of CDA and corpus linguistics effectively in order to develop a model to be followed with a view to reaching perfection in the process of this sensitive type of translation.

Sameh Hanna (2006), for example, uses Arabic translations of Shakespeare's great tragedies in order to see whether it is possible to apply the sociological model developed by Pierre Bourdieu to the field of drama translation. Likewise, the translation model developed by the $\mathrm{BBC}$ organization may be tested to check whether it is possible to be applied to the field of news translation. The idea of establishing translation criteria or a model to be followed had always occupied translation theorizers from Cicero up to now. For example, Etienne Dolet sets out five principles for producing a good translation; they are general rules on content, style, choice of words and cohesion (Munday, 2016: 44). Khalid Tawfiq (2017) sets more specific rules for journalistic translation. More specificity is sought here by choosing the $\mathrm{BBC}$ as a case study.

\section{Setting the Problem:}

how to investigate external factors affecting individual translators, the circumstances in which translations take place and how translations influence the receiving culture. Examples include political, economic, social and ideological factors, such as the impact of state censorship on translations or how the 
reception of translations is influenced by a particular intellectual or economic climate (Saldanha \& O’Brien: 205).

Dealing with the internal relations of the text does not seem to represent a real problem to the translator, especially if he masters the target and source languages. The problem with journalistic translation is the external relations of the text, i.e. how do translators deal with discourse as social practice? How are social actors represented? For example, North Korean president is sometimes reconstructed in translations: source text referring expressions like "North Korean dictator" or "Great Learder" are rendered by his name or the pronoun 'he'. In so doing, the negative or positive opinions in the source text are neutralized (ibid: 92). Does this happen in the BBC translations? This question and others are explored in the following sections. To be conceptualized, primary questions here are broken down into sub-questions that are more specific.

\section{Research Question:}

What is the true policy of rendering news from a language to another when an agency has more than one language section? How do BBC translators produce stories in more than one language? What is the difference between their method and the methods of similar national and local agencies in the Arab world? To what extent may Arab agencies benefit from the $\mathrm{BBC}$ experience and avoid its mistakes in the field of translation? What is the effect on BBC translation quality ${ }^{i}$ when time pressure ${ }^{i i}$ is increased? ${ }^{\text {iii }}$ 
Can the BBC Arabic/English be considered varieties of language ?v $^{\text {To }}$ what extent translated texts of the $\mathrm{BBC}$ website differ from non-translated texts in the same language? CL may be used to answer this question by contrasting the linguistic qualities of two texts: one of them is a translation, while the other is not. What strategies do translators apply? These questions contribute to news and media translation quality assessment. Researchers need to take into account the circumstances under which the discourse is produced (e.g. who commissioned a translation, for what purpose, gender and professional background of translators and editors). The study is also an attempt to establish a comprehensive media translation qualityassessment model:

Many models of quality assessment have been developed in translation studies... no model has brought textual, contextual and functionalist criteria together, nor has such a model been validated through empiricalexperimental research (ibid: 96).

\section{Methodology:}

The research model here is highly sociological and culturist. It seeks to uncover the complex social, political, cultural and ideological forces which shape media translation practices. The BBC translation activity on the English and Arabic websites is a case study as regards these forces. Bill Gillham (2000) shows the importance of case studies as follows: 
A case study can also challenge established theories and it may point to the need for a new theory in areas that have not received sufficient scholarly attention. Thus, the application of theory to cases is one way of providing feedback to the theorist, and may lead to additions or modifications to existing theories in order to accommodate puzzling aspects of a case. Researchers often engage in case study research when they have hunches about what modifications could be made to existing theory, or how different findings from those reported in the existing literature could be obtained (10).

Better exploration of the research question can be achieved via a coherent integration of different methods of research. Macro-level and micro-level units of data will be analyzed to explore the cultural and linguistic aspects of the translational and translatorial actions (Taher Okasha: 37). A whole news article is a macro unit, whereas a micro-unit may be a word, a phrase or a sentence. Translation unit is a segment in constant transformation that changes according to the translator's cognitive and processing needs (Saldanha \& O'Brien: 120). The larger the segment is, the more professional the translator. Determining the translation unit would help researchers establish the needs of media translation professionals. Purposive sampling is adopted by 
depending on "pre-defined critical parameters"(ibid: 34). The population under analysis is a group of texts carefully selected to explore the qualitative aspects mentioned above. The analyses are done in light of Fairclough's approach to CDA that depends on a method of three components: that is, description, interpretation and explanation:

The method of discourse analysis includes linguistic description of the language text, interpretation of the relationship between the (productive and interpretative) discursive processes and the text, and explanation of the relationship between the discursive processes and the social processes. A special feature of the approach is that the link between sociocultural practice and text is mediated by discourse practice (Fairclough, 2013: 132).

The merit of Fairclough's method is that it mingles the linguistic, the cognitive and the social for the benefit of a comprehensive translation analysis. Description is the first step of this analysis in which internal relations of vocabulary, grammar, cohesion, etc. are discussed. Secondly comes the interpretation process where internal relations are interpreted in terms of genres, styles and discourses within the text. This is followed by the last step of explaining external relations or discourse as a social practice. 
In some cases, critical discourse analysis and corpus linguistics are used together to examine translated texts and produce more general results. A corpus is "a large collection of authentic texts that have been gathered in electronic form according to a specific set of criteria" (Bowker and Pearson, 2002: 9). BBC corpora are used to do a CDA while CL helps in finding how translated texts of the BBC are semiotically different or similar to non-translated texts. Such bidirectional parallel-corpora are used to investigate features of translated language and reach authentic results. They combine both translated and non-translated texts in the same language.

Larger monolingual corpora may be consulted as reference or control corpora to explore whether a usage is normal or not; larger corpora add more authenticity to evidence and results, and help the researcher assess the translators' degree of creativity by tracing the new structures they standardize or add to the lexicon of the target language. New structures are standardized and grammaticalized by the media everyday. Lexical and grammatical creativity of the BBC translated texts will be assessed via DA and CL.

Thus, the methodology makes the study have two dimensions: linguistic and social. This runs in line with Halliday's SFL that views language as a semiotic social system. Effort is done to provide to the research question answers that can be generalized beyond the texts under study. Such generalization cannot be achieved by CDA alone which has been criticized for not addressing linguistic or social issues in a comprehensive way. "One of the advantages of using corpus analysis tools is that we can easily account for 
all the instances of an item in a corpus. This can help to make the analysis comprehensive" (Saldanha and O'Brien: 92) and help in building a more comprehensive newspaper corpus. The importance of using CL with CDA is that CL restricts bias and generalizes results, and thus solves some of the weaknesses of CDA (ibid: 59). With the help of CL, results and limitations of CDA can be generalized.

However, one limitation of corpora is that even if they can show that there is an association between two variables, they cannot explain why that is the case. This problem is solved in the present paper by showing why two or more linguistic or cultural variables related to the translational or translatorial act are connected to each other. Another problem with corpus analysis tools is that they are best suited for the investigation of features below sentence level, and they present the analyst with fragments of language which are removed from the environment in which they were designed to be displayed. In the following analysis, there is an attempt to develop corpus analysis tools to exceed the limitations of the below-sentence level. Rather than using closed theoretical frameworks and illustrating them with examples that fit certain claims, this study depends on approaches that proceed inductively ${ }^{\mathrm{v}}$ by selecting problems that are then explored through in-depth case studies and ample data collection:

But if the use of corpora is to maximally fulfil its potential, it should be used in conjunction with other tools, that is, introspection, observation, 
textual and ethnographic analysis (Juliane House, 2011: 206).

\section{Translation in the $\mathrm{BBC}$ as an adaptation of language and social actors:}

A translational product depends on three dimensions of causation: the translator's cognition (translator's knowledge, attitude, identity, skills), the translation event (translator's brief. payment, deadlines) and the socio-cultural factors (ideology, censorship, cultural traditions, audience) (Chesterman, 2017:21). The question is: does this model apply to BBC translatorial action? Translating news stories on the $\mathrm{BBC}$ websites is a process of adaptation. BBC editors adapt the story, whether political, scientific, sports or economic, to make it accessible to the reader:

\section{Translation:}

"One of the most important features of a title is that it should be clear, attractive, not misleading the reader, and including key words that help in the search process. Whether the story is political, scientific, sports, economic, etc. the title remains a decisive source of the information that the reader always wants to catch; it gives hints to the content of the story. If the reader finds details not agreeing with the title, he will not be interested in the website"vi. 
The quotation above means that there is a process of adaptation in the $\mathrm{BBC}$ translation sections to make the headlines clear and attractive; a clear and attractive title in one culture may not be so in another. Clearness and attractiveness may require manipulations: for example, the ST word "poach" in the following example literally means but it should be manipulated to agree with the context of the translation:

"The Aquilaria tree from which agarwood is harvested is the target of poaching"

$$
\text { تشكل "أثنجار العود" التي يُحصل منها على "خشب العود" هدفاً لعمليات الصيد الجائر }
$$

The example above is a comment on a picture, translated from English to Arabic. The word "poaching" is rendered as الصيد الجائر. It does not seem to be a precise translation for the topic is about misusing trees rather than catching game. Keen search of Arabic corpora on that topic prove that الصيد الجائر is used only with animals. Thus, الاستغلال بدون ترخيص or الاستخلال الجيد الجائر is better than الصنائر. For adaptation purposes, it may be argued that الصيد الجائر is a metaphor that may easily be understood by Arab readers. Another option is to translate the whole sentence in a different way:

$$
\text { الحصول على خشب العود بصورة غير شرعية من أشجار العود }
$$

Or

$$
\text { التعدي على الأشجار للحصول على خشب العود }
$$


are collocational and more acceptable in the Arabic context than الصيد الجائر. This recalls the idea whether the translator brings the text to the readers or should "move the reader towards the writer" (Munday, 2016: 48). Moving the reader towards the culture of the source text may have something to do with the relations of power and dominance. The influence of the English texts on Arabic ones is more than vice versa. The more dominant party influences the language of other parties resulting in producing a foreignizing or alienating method of translation. The oddly unArabic style may be the best way of preserving the source culture force. Thus, there may be an argument against considering الصيد الجائر a literal rendering for a simple reason that there is not full agreement on definition of concepts as 'literal' or 'free' translation. "Translation theory in the second half of the twentieth century made various attempts to redefine the concepts 'literal' and 'free' in operational terms, to describe 'meaning' in scientific terms, and to put together systematic taxonomies of translation phenomena" (ibid: 50). Many invisible forces control media translation and interpreting. David Katan (2014) discusses some of these forces:

Consumer capitalism and popular television are the two main ideologies moulding an interpreter's performance on television. These two apparently invisible forces form the base layer of an iceberg model, and are creating 
significant changes in the interpreter's traditional habitus (131).

These invisible forces also apply to translated material on media websites. They influence the performance of media translators, and even change the performance of language users: expressions like عنف استثنائي (i.e. exceptional violence), يلعبب دوراً (i.e. to play a role), احتواء المشـاعر (i.e. containing/controlling feeling), etc. were introduced into Arabic through translation; it would be said that they were lexicalized through translation mistakes. A careful corpus linguistic analysis shows that the three collocations are new in the Arabic language and have no traces in classical Arabic texts. It is like the word فظيع (fadhi', i.e. horrible) used by young men and women in Egypt these days meaning "wonderful", although in the eighties of last century it did not have such sense.

Thus, the translator may regulate his strategies and performance to serve certain ideologies and disseminate the ideas of those who have power and dominance. Such translatorial actions may happen without seeming unfaithful to the source text. According to Katan, the degree to which the audience is entertained is called the comfort factor (ibid: 131). Satisfying desires of audience is very important because they are considered consumers of a service, not merely people who read news. Communication in this case does not happen through language only. Visual and other 
multimodal stimuli are used. There are advertisements being shown on the website while reading the news. The readers (or consumers) of the website must feel a kind of attraction that prompts them to go on with the website and revisit it regularly. For example, the following English title of a news story on the BBC starts with the phrase 'Christchurch shootings' whereas in the Arabic version of the story on the Arabic website, the Arabic rendering of the title starts with the phrase 'قصص بطولية' (i.e. stories of heroism). This shift in translation causes a change in the representation of social actors who interact with the text; in the ST they are neutrally represented while in the TT there is a focus on the notion of heroism which appeals more to the sensations of the potential readers from the Arab world, or the potential consumers of the website whose satisfaction is of a great priority. There is also a trace of the narrative theory here (Mona Baker, 2006), in the sense of translating in line with the stories and narratives that satisfy the target reader. Such satisfaction, however, has to be achieved without jeopardizing the authenticity of the source text or the good reputation of the institution as is clear in the following professional rendering:

Christchurch shootings: Stories of heroism emerge from attacks

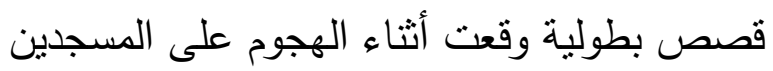

The following news story in Arabic and English has been quoted from the two websites of the BBC at the same 
time, on March $19^{\text {th }} 2019$, at 10 p.m. A DA and CDA of the two versions reveal more on the policy of rendering in that institution:

(For purpose of analysis, paragraphs in the $\mathrm{ST}$ and TT are numbered)

\section{US-backed Syrian fighters} overrun IS encampment

( 3 hours ago - Syrian civil war)

1- US-backed Syrian

fighters are reported to have overrun an encampment that made up most of the last patch of territory held by the Islamic State group.

2- The Syrian

Democratic Forces (SDF) alliance said militants refusing to surrender had pulled back to a sliver of land along the River Euphrates south of Baghuz, and that clashes continued.

3- Although it warned the battle was not over, some fighters began celebrating.

4- Baghuz's fall would bring an end to the "caliphate" proclaimed by IS

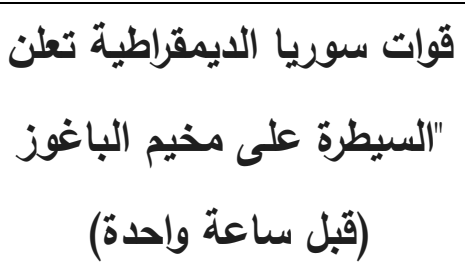

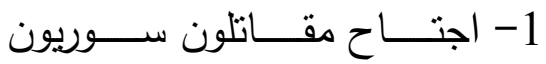

مدعومون مـن الولايـات المتحدة آخر جيب لتنظيم الدولة الإسـامية بـالقرب من الحدود العراقية.

2- وقــال مقــاتلو قــوات ســـوريا

الديمقراطية إن مسلحي التنظيم رفضوا الاستسلام، بينما احتمى أفراد عائلاتهم فـي قطعـة أرض على نهـر الفـرات

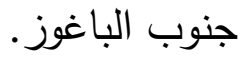

3- وحذرت قوات سوريا الديمقراطية مـن أن المعركـة لــم تتتـهـه بعـد، لكـن مقاتليها بدأوا بالاحتفال.وبحسب بيان صـادر عن المركز الإعلامسي لقوات 
in 2014.

5- The jihadist group once controlled 88,000 sq km $(34,000 \mathrm{sq}$ miles $)$ of land stretching across Syria and Iraq, imposed its rule on almost eight million people, and generated billions of dollars from oil, extortion, robbery and kidnapping.

6- After five years of bloody battles, local forces backed by world powers have driven IS out of all but a few hundred square metres.

7- But the group is by no means defeated. US officials believe IS may have 15,000 to 20,000 armed adherents active in the region, many of them in sleeper cells, and that it will return to its insurgent roots while attempting to rebuild.

8- How many militants are left in Baghuz?

8- It is not known. At the start of March, when the
سوريا الديمقراطية، فإنها قد "سيطرت على مخيم الباغوز بشكل نهائي، لكن كــان لا بــزال بعــض الإرهــــيتين يتحصنّنون في بعض الجيوب بمحاذاة

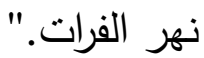
4- ويضــع سـقوط البـاغوز

نهايــة لدولــة "الخلافـة" التـي أعلنهــا تتظـيم الدولــة الإســلامية فـي عـام .2014

5- وكان التتظيم قد تمكن من

بسـط نفـوذه على مـا يقـرب مـن 8

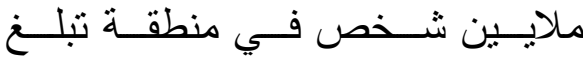
مســاحتها 88 ألـف كيلـومتر مربـع، واسـنطاع أن يجنـي مليـارات الدولارات من عائدات النفط والسرقة والخطف. 6- وفي النهايـة، وعلى إثر معـارك طاحنـة، تمكنـت قـوى محليـة مدعومـة مـن أطـراف دوليـة مـن دحـر مسلحي التنظيم. 
SDF began its final assault on the village, commanders estimated there were a few hundred militants holed up inside.

8- But the Kurdish-led alliance was forced to slow its offensive after it emerged that a large number of civilians were also there, sheltering in buildings, tents and tunnels.

9- As many as 20,000 children and women - many of them foreign nationals have since been evacuated to an SDF-run camp for displaced people at al-Hol, swelling its population to 70,000 and overwhelming aid workers. Several thousand men have also surrendered and been taken to separate SDF detention centres.

10- Militants who chose to stay in Baghuz continued to put up fierce resistance, deploying suicide
7- ويعتقد مسؤولون أمريكيون

أن للتنظيم أتباعا في المنطقة قد يتراوح عـددهم بـين 15 ألــف و20 ألــــ شـخص سـيحاولون تجميـع أنفسـهـ هـ والعودة للقتنال.

8- وكانـــت قـــوات ســـوريا

الديمقراطيـة قد قالت في بدايـة شهر مارس/آذار إنها بدأت الهجوم النهائي علـى البـاغوز ، لكـن التحـالف الـــي يقوده مسـلحون أكراد اضطر لإبطـاء الهجوم بعد أن اتضـح أن عددا كبيـرا من المدنيين موجودون في القرية. 9- وقد أجلي مـا يقارب 20

ألف امرأة وطفل منذ ذلك الوقت إلى مخيم تـديره قوات سـوريا الديمقراطيـة

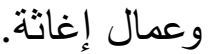

9- واستشـلم آلاف المسـلحين ونقلوا إلى مخيمات منفصلة. 10- واستمر المسلحون الذين 
bombers and car bombs, but by Monday they had been driven back to a small patch of open farmland next to the Euphrates that was covered in tents, vehicles and foxholes.

11- On Tuesday morning, SDF spokesman Mustafa Bali said it had taken control of the encampment and that the last militants had retreated to the riverbank.

12- "This is not a victory announcement, but a significant progress in the fight against [IS]," he cautioned in a Twitter post. "Clashes are continuing as a group of [IS] terrorists who are confined into a tiny area still fight back."

13- Mr Bali added that hundreds of sick and wounded militants had been captured by the SDF as it took the encampment and that they had been taken to hospitals.

$$
\text { Are SDF fighters }
$$

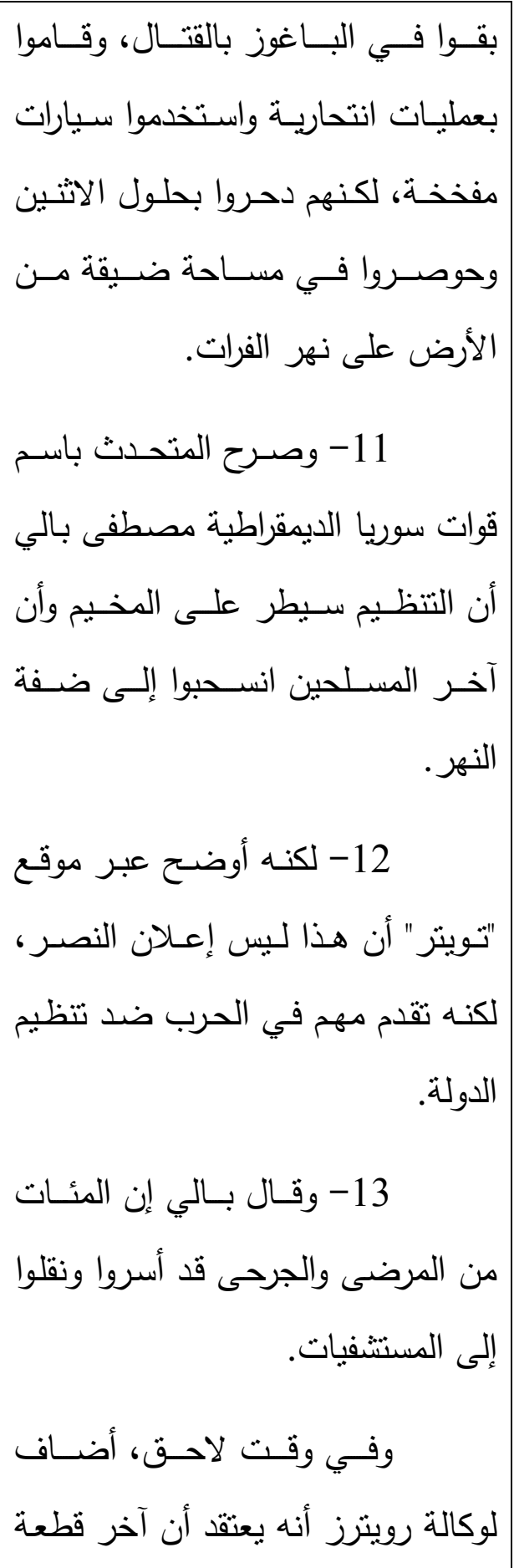

بقــوا فــي البــاغوز بالقتــال، وقـاموا بعمليـات انتحاريـة واسـتخدموا سـيارات مفخخـة، لكنهم دحروا بحلـول الاثتين وحوصـروا فـي مسـاحة ضـيقة مسن الأرض على نهر الفرات. 11- وصـرح المتحـدث باسـم قوات سوريا الديمقراطية مصطفى بالي أن التتظـيم سـيطر علـى المخـيم وأن آخـر المسـلحين انسـحبوا إلـى ضـفة

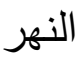

12- لكنـه أوضـح عبر موقع

"تويتز " أن هـذا لبس إعـلن النصـر ، لكنه تقدم مهم في الحرب ضد تتظيم الدولة.

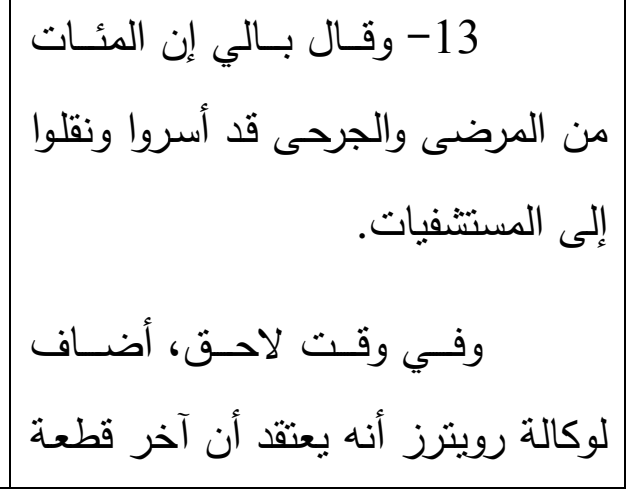


celebrating too early?

On Tuesday afternoon, the BBC's Aleem Maqbool saw lorries leaving Baghuz packed with what he was told were hundreds of militants, as well as SDF fighters celebrating on their return from the front lines.

Jiaker Amed, spokesman for the Kurdish militia that dominates the SDF, told our correspondent they were celebrating "a victory for all humanity".

Mr Amed declared that all IS territory in Baghuz had been retaken, although he admitted that some militants might be hiding underground in tunnels.

Later, Mr Bali told Reuters news agency that fighting was continuing and that militants remained "in several pockets". "Their presence is not limited to a defined geography," he added.

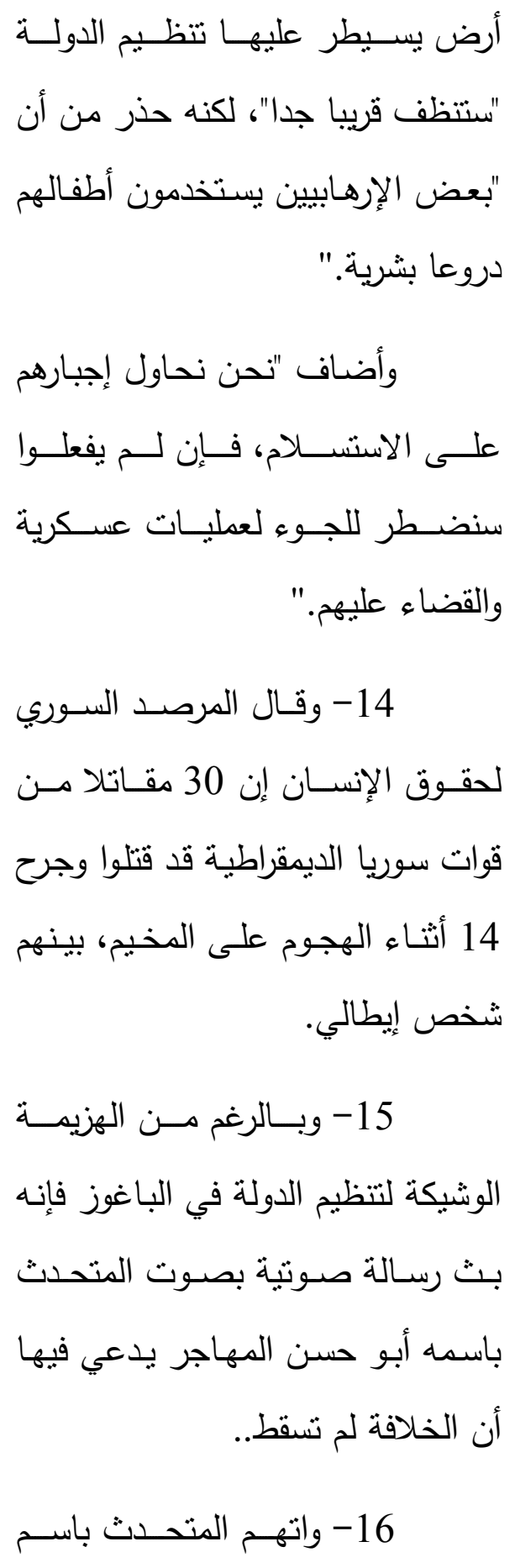




\begin{tabular}{|c|c|}
\hline $\begin{array}{l}\text { 14- The Syrian } \\
\text { Observatory for Human } \\
\text { Rights, a UK-based } \\
\text { monitoring group, meanwhile } \\
\text { reported that at least } 14 \text { SDF } \\
\text { fighters were killed and } 30 \\
\text { others injured by IS gunfire } \\
\text { and landmine explosions as } \\
\text { they attacked the } \\
\text { encampment. } \\
\text { An Italian man fighting } \\
\text { for the SDF, Lorenzo Orsetti, } \\
\text { was killed on Sunday. } \\
\text { 15- Even with its } \\
\text { defeat in } \\
\text { imminent, IS released a } \\
\text { defiant audio recording } \\
\text { purportedly from } \\
\text { spokesman Abu Hassan al- } \\
\text { Muhajir that asserted that the } \\
\text { caliphate was not over. } \\
\text { 16- Muhajir accused } \\
\text { US President Donald Trump } \\
\text { of falsely" announcing } \\
\text { victory over IS in Syria in } \\
\text { December, and insisted IS } \\
\text { leader Abu Bakr al-Baghdadi } \\
\text { was alive. }\end{array}$ & 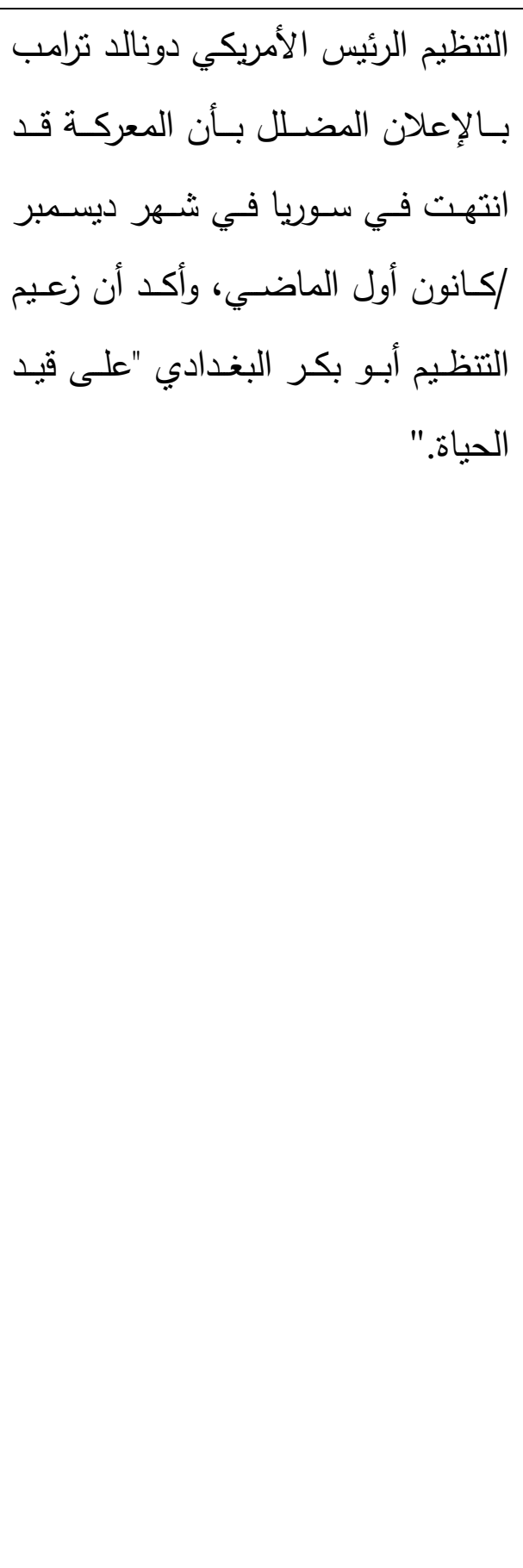 \\
\hline
\end{tabular}


Additional information below Arabic and English titles show that the story appeared on the Arabic website two hours after the English version was published. Thus, the Arabic version is made, edited and published only within two hours. This recalls the question asked earlier about the effect of time pressure on the quality of translation on the BBC websites. The phrase 'Syrian civil war' under the title is ignored in the Arabic version. Is it a kind of localization to satisfy all potential readers/customers of the website? The title in Arabic is almost completely different from the source text in English. It may have been changed for the same reason: that is, to satisfy all social actors who may use the website and interact with the text in Arabic. The English phrase 'USBacked' is not rendered into Arabic. The Arabic rendering may look attractive and patriotic to the Arab reader; avoiding 'US-Backed' makes a local reader feel a kind of independence and free ideology not swayed by external forces, dominance, ideologies or other influences. Hence, the Arabic title is localized successfully without being influenced by the element of time pressure. Credit here goes to experienced translators, localizers and editors who are also expected to treat the content in the same professional way. A contrastive discourse analysis of the two texts may help in judging the quality of translation. The question here is: does the Arabic translation succeed in rendering the discourse markers in the English text? Or the discourse markers are manipulated to satisfy the taste and needs of the target audience? 
The problem with rendering some news stories is that some source texts do not satisfy the seven standards of textuality: cohesion, coherence, intentionality, acceptability, informativity, situationality and intertextuality. A flouted standard in the source is automatically flouted in the rendering, except in cases of localizing by expert editors and translators. In other words, blame is not to be put on the translator all the time in cases of lack of cohesion or coherence in the translation. It is like a play or a movie that is not interesting because the real life it reflects is not interesting, not because the artist has a certain problem with his art. For example: the English source text above is composed of very short paragraphs and the same plan is applied in the translation.

News is not presented in the form of an essay composed of long paragraphs. It is rather in the form of separate sentences or small paragraphs of three lines or onesentence paragraphs. The big meal of the news story is divided into small meals not to overstuff the targeted reader. The same policy is nowadays applied in other famous organization like the Guardian where a similar news story is presented in small paragraphs as well ${ }^{\text {vii }}$. Cohesive markers in the $\mathrm{BBC}$ example are used to connect these separated onesentence paragraphs: first and second sentences are connected via lexical cohesion, "US-backed Syrian fighters" in the first sentence stands for "the Syrian Democratic Forces" in the second one. Likewise, "militants" and "jihadist group" stand for "Islamic State group". Other cohesive 
markers like multivalence, antonymy and deictic markers are used to hold parts of the text together.

The Arabic version is 439 words while the English is 669. Some parts of the English version are not rendered into Arabic. Untranslated paragraphs are not numbered. The Arabic version also includes information that is not in the origin, which may make the reader doubt whether the longer بالقرب 1 English version is an ST: for example, in paragraph (i.e. near the Iraqi borders) is not in paragraph 1 in the English version, in which "an encampment that made up most of the last patch of territory" is rendered as آخر جيب (i.e. last patch). Thus, the same paragraph includes translation by addition and omission at the same time. بالقرب is added because, from a geopolitical point of view, the Arab reader is supposed to be anxious to know the exact location of the militants. As for آخر جيب, there seems to be no reason to omit something form the ST. It may have been better to render it as الجزء الأكبر من آخر جيب. Such internal relations on number of words and details in both ST and TT may externally be explained that details are omitted in the translation because the social actors are represented in a different way: the writer of the Arabic text wants to focus on the fact that terrorists are defeated without mentioning details on them, being something trivial from his and most readers' point of view. In so doing, the orientation to difference in both texts is not the same. 
Paragraphs 3 and 4 in both source and target seem identical. The Arabic rendering is well constructed, especially as far as cohesive markers are concerned: "although" is not literally rendered as بالرغم من but the concessive clause is successfully transferred to Arabic by the word "كن "Some" is not also translated because its meaning can be inferred: مقاتليها بدأوا الاحتفال does not mean that all fighters do the action. Thus, the meaning of "some" is felt without using بعض.

In paragraph 5: "jihadist group" is rendered as التنظيم. Rendering such titles and names depends very much on the narratives in the mind of the institution or the person who translates. However, in paragraph 11, the word التتظيم is mistakenly used because it causes ambiguity: the ST "it had taken control of the encampment and that the last militants had retreated to the riverbank" is rendered as أن التظيم سيطر which means that SDF forces is rendered as التنظيم.

In paragraph 5 too, "88,000 sq km (34,000 sq miles)" is rendered by using square meters only because Arab readers are not interested in knowing a measurement in miles. "Extortion, robbery and kidnapping" may be rendered as is not used for it is embedded in 
السرقة. Additionally, السرقة والخطف is more collocational for a news-article context than الابتزاز والسرقة والخطف.

Paragraph 6 is twenty four words, whereas the Arabic version is only seventeen words. Details are omitted in the translation: "after five years" becomes وفي النهاية "bloody battles" is given as دموية معارك طاحنة and not. When "bloody" is given as طاحن a mismatch of tenor arises; طاحن conveys another attitude (Mary J. Schleppegrell: 22) for it is more euphemistic than دموي (i.e. bloody) that recalls blood shedding and the colour of blood. The word طاحن, on the other hand, recalls the process of grinding without the horrific image of blood. Thus, as far as Fairclough's method of analysis is concerned, it might be argued that the interpretation level in ST and TT is different because the discourse in the Arabic style is less severe although the two texts belong to the same genre.

The structure "have driven IS out of all but a few hundred square metres" in paragraph 6 is also condensed to تمكنت من دحر التنظيم (i.e. managed to defeat the militants). These changes and condensation are one more example of localization, omitting some details of the defeated party. The same strategy is applied in paragraph 7 where the two structures "But the group is by no means defeated" and "sleeper cells" are not translated. There are mismatches in the amount of information where some sentences are shortened, but cohesion is not lost in the translation, except for the 
aforementioned التنظيم in paragraph 11. The three paragraphs that take number 8 (67 words) are condensed to only one paragraph (36 words) in the Arabic version. On the contrary, additional information not mentioned in the ST is added in some cases as is in the following example:

Brexit: Theresa May promises White Paper on EU exit plan

"Theresa May has announced the government will set out its Brexit plans in a formal policy document.

During Prime Minister's Questions, she said she recognised an "appetite" for a White Paper on her "bold" proposals for negotiations with the EU".

الحكومة البربطانية تعد بإصدار وثيقة استشارية تثرح سياسة الخروج من

$$
\text { الاتحاد الأوروبي }
$$

قالت رئيسـة الوزراء البريطانية، تريزا مـاي، إن الحكومـة ستصيغ خطط سياسـة

$$
\text { الخروج من الاتحاد الأوروبي في وثثية حكومية رسمية (كتاب أبيض). }
$$

جـاء كـلام مـاي في سياق جدل أثتاء ردهـا على أسئلة في جلسـة المسـاءلة الأسبوعية في مجلس العموم.

وقالت رئيسة الوزراء البربطانية إنها تدرك أن ثمـة رغبة في رؤية "كتاب أبيض" (ورقة بيضاء) يشرح "خطتها الجريئة."

و الكتاب الأبيض، عادة، هو وثثقة حكومية أو دليل يشرح سياسـة حكوميـة إزاء قضـية محددة ويوضـح أسسـها وقد تتضـمن مقترحات لتشـريعات مستقبلية في 
The passage above shows an important problem not to be overlooked by the media translator: that is, how to "provide an acceptable compensation for an inescapable cultural loss" (Bakri Al-Azzam, et al. 2015). Culture creates translation challenges, and the best way to render a title including an alien cultural concept is to explain it in the title, then propose a creative translation for it in the content. Accordingly, "white paper" is rendered in the Arabic version paraphrastically as وثيقة استشارية rather than the ambiguous "كتاب أبيض" that might confuse the Arab reader and discourage him from reading the content of the news story. كتاب ابيض Then, in the content, "white paper" is rendered as and explained in detail at the same time; the last underlined sentence in the translation is not in the English ST. In so doing, the translator succeeds in giving a brief, attractive and informative title, and adding essential information to the TT content that may, if avoided, cause a communication gap. Thus, rendering the external relations of discourse as social practice here required translation by addition to make the explanation level in Fairclough's method equal in both source and target texts, unlike the previous example in which some information is omitted to reconstruct the text in order to represent social actors in a certain way.

In the following example, too, social actors are similarly represented in both ST and TT where Trump describes North Korean leader as a "smart cookie": 


$$
\text { الرئيس الأمريكي ترامب: الزعيم الكوري الثمالي كيم جونغ-أون ماكر جدا }
$$

The BBC translators render it as ماكر جدا while in Alwatan, an Egyptian newspaper, محنك is used instead of ماكر:

$$
\text { "ترامب" يصف زعيم كوريا الثمالية بـ"المحنك" }
$$

$\mathrm{BBC}$ translation seems more successful because the informal expression "smart/tough cookie" viii means "someone who is clever and successful, and knows how to get what they want". To render the informal flavor of the source text, it is better to use مكار or مكر. Kieran O'Halloran (2011) points out "how the border shift between public and private discourse in the late twentieth/early twenty-first century is revealed in texts where subjects are positioned in a more informal, chatty manner" (450). Blending formal and informal levels of language became very common, especially as far as Donald Trump rhetoric is concerned. He uses different genres, discourses and styles at the same time, and suddenly changes his tenor. Moving smoothly between levels in the target language and dimensions of the context needs great skills on the part of the translator to overcome the problem of the unsettled boundaries between different social and political uses of language that reflect hints of ideology, power and dominance. Reflecting Trump's informal voice in the Arabic version is a good point in the BBC translation, unlike their treatment of the passage above on ISIS in which details are added or omitted to sway the relations of power implied in the ST. 
Also in another story on relations between the UK and Saudi Arabia, explanatory translation is used in rendering the word 'candour' to render the deep meaning:

"There is candour in UK-Saudi relations."

Candour is rendered in the Arabic version as الصدق والصراحة; this agrees with Longman LDOCE definition of "candour" as: "the quality of being honest and telling the truth, even when the truth may be unpleasant or embarrassing". Adding the word الصراحة achieves a better representation of discourse as social practice in TT, and reflects the openness expressed in ST as regards the orientation to difference in the text. Thus, explanatory translation is successfully applied; thereby the exact voices and tones in the ST have been transferred.

Translation strategies above, especially the techniques of condensation and addition, show that translators in the $\mathrm{BBC}$ practise not only DA and CDA while doing their job, but also they practise PDA by which something may be added or deleted in order to present facts in a certain way that satisfies one narrative or another. Such a PDA is also clear in the example below on the relations between Iran and the US:

وإشنطن تعلن عدم تمديد إعفاء بعض الدول من العقويات على شراء النفط

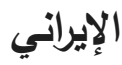

(قبل 23 دقيقة)

Iran oil: US to end sanctions exemptions for major importers

(43 minutes ago) 
Those two titles appeared on April 22 $2^{\text {nd }} 2019$. The Arabic story appeared 20 minutes after the English version. Thirteen words in Arabic are for ten ones in English. This is another example of localization on the BBC. "Iran Oil" is fronted in the ST but in the TT it is moved to the end of the title; the localizer is successful here because, from a Western point of view, oil is a major player in the problem, whereas, from an Arab standpoint, it is not a problem of oil only; it is rather a matter of dominance and power relations. Hence, Washington is fronted instead of 'Iran oil'. The problem with this localization from English to Arabic is that it refutes the famous maxim in Arabic stylistics that اللغة العربية لغة الإيجاز i.e. Arabic is the language of brevity. Other brief renderings may be better.

\section{Acceptability and Collocationality of Arabic on the BBC:}

Although the translated materials on the $\mathrm{BBC}$ are generally excellent, they are not devoid of collocational or other mistakes: In some cases, the mistakes are grave as in a story about an accident where the sentence "I was in a car park when I heard screaming” is rendered as ix،، كنت في سيارة "بالمنتزه عندما سمعت أناساً يصرخون "park" is rendered by an Arabic word meaning "garden", not the "parking lot". Such grave mistakes should be avoided in an international organization like the $\mathrm{BBC}$. Another grave mistake is that of ambiguity when SDF is rendered as التنظيم in the passage above. 
As for mistakes of collocationality, the story above on (i.e. agarwood) is an example where الصيد الجب العود (i.e. poaching) is not collocational with الأثتجار (i.e. trees). Another uncollocational rendering is in the following example:

$$
\text { "وكان العلماء ينوقعون هذا الحدث، إذ إنهم كانوا ينابعون تطور شرخ الجني }
$$

"Scientists had been following the development of a large crack in Larsen's ice for more than a decade."

The problem above is that "development" collocates with "crack" in English whereas in Arabic نطور does not seem to collocate with نشخ; a word like ازدياد شرخ would be better. Various studies have been written on collocationality and how to measure it (Adam Kilgarriff, 2006). The issue of collocations in Arabic needs more care. In English, many dictionaries have solved the problem. Books in this field in Arabic are very rare, especially as far as modern Arabic is concerned.

Not only lack of collocationality makes a translation unacceptable. Lack of commonness is also a defect in some translations. In the following example, the common word is replaced by the transliterated word العقيق that is originally derived from Sanskrit:

$$
\text { لماذا يزداد الطلب على أحجار الأوبال الكريمة؟ }
$$

Glittering prize: The booming demand for opals 
The word opal means العقيق in Arabic. The question is: does the choice of أوبال agree with the contextual factors of the translational action? Contextual factors are of great importance as a dimension in the translation process. Most translators claim that they allude to the context; they always stress the fact that contextualization is important but in many cases no traces of contextual factors are found in the translation.

If the words عقيق and أوبال are surveyed in the Arabic corpora, we may have some evidence that shows which one is better. However, the commonness alone of a structure is not enough evidence. عقيق is a famous word that has a cultural weight in all cultures of the Arabs. It refers to a precious stone that may be red, yellow or white (Edward William Lane, vol. 5: 2096). From a CL point of view, it is better to use عقيق than أوبال.

Other inaccuracies are because of ambiguity in the translation as in:

"But there was no sign of the chaos that affected travelers when the first version of the ban was brought in at a few hours' notice in January."

وليس هنالك دليل على حدوث فوضى تؤثر على حركة المسافرين كما

حدث في النسخة الأولى من قرار الحظر التي صدرت في غضون ساعات قليلة في شهر يناير/كانون الثاني

The expression "at a few hours" notice" in the example above is rendered in the Arabic version as صدرت في غضون 
whose meaning is not clear. The true rendering should be something like دخلت حيز التنفيذ دون إعطاء مهلة لتصحيح الأوضاع غير ساعات قليلة فقط. Such mistakes should not be found in big institutions that everybody uses all over the world. In the same example, the literal rendering النسخة الأولى for "first version" does not seem suitable because النسخة is a written copy; importing it to such collocations as النسخة الجديدة من (i.e. new version of the program) does not agree with the collocational behavior of standard Arabic. عندما صدر قرار is more natural by avoiding overlap between versions and copies.

Sometimes, there seems to be a mistake in the translation, but it is not really an error. It is a kind of manipulation to produce a more acceptable translation: for example, the word "excruciating" means شديد but in the following example from the health section in the BBC website:

\section{Vaginal mesh led to 'excruciating pain'}

it is translated in the Arabic section as مزمن:

$$
\text { علاج الفتق في بريطانيا يؤدي لآلام مزمنة }
$$

Does "excruciating" mean مزمن? According to John Milton Cowan (1980), it means نكديد, مبرح , نمرني. The word here means "chronic". Maybe, it is used to express the 
idea of great pain which is meant by the word "excruciating". According to Longman Dictionary, it means "extremely painful". So, the title should be rendered as: علاج الفتق في بريطانيا يؤدي لآلام شديدة. However, the translator is successful in alternating the literal meaning of شزمن to مزيد because the content of the news article is about chronic pains of the vaginal mesh.

The same strategy is applied with the word "ruins" in:

"IS held Palmyra and its nearby ruins"

$$
\text { وكان تتظيم الدولة قد سيطر على تدمر والآثار المحيطة بها" }
$$

The word "ruins" literally means “بقايا مبان/مبان مدمرة" but here the rendering بقايا المباني in the tourist city of Palmyra are ruins of monuments.

Sometimes, to prove the acceptability of a translational choice, a corpus analysis is a must. For example, the concept of الخطاب الديني is rendered as "religious rhetoric" or "religious discourse". The following two tables give some statistics about the occurrences of the two renderings on the $\mathrm{BBC}$ Arabic and English websites:

1- Religious rhetoric

\begin{tabular}{|l|l|}
\hline 22 Oct & So it seems that while we have members of the \\
al-Qaeda hiding behind a human shield in a \\
foreign country uttering religious rhetoric to \\
enrage Muslims against Westerners, we also \\
have an antagonistic Press trying to nurture \\
racism against Muslims!
\end{tabular}




\begin{tabular}{|c|c|}
\hline $\begin{array}{l}21 \mathrm{Apr} \\
2010\end{array}$ & $\begin{array}{l}\text { I would say politicians are more religious in } \\
\text { their rhetoric than they were. }\end{array}$ \\
\hline $\begin{array}{l}5 \text { Nov. } \\
2004\end{array}$ & $\begin{array}{l}\text { Family and religion are important to Latinos, } \\
\text { which is why many fell victim to the } \\
\text { Republican's "family and religious values" } \\
\text { rhetoric. }\end{array}$ \\
\hline $\begin{array}{l}10 \text { June } \\
2005\end{array}$ & $\begin{array}{l}\text { Economic, cultural and educational integration } \\
\text { seems to take an upper hand over entrenched } \\
\text { political and religious rhetoric and } \\
\text { fundamentalism. }\end{array}$ \\
\hline $\begin{array}{l}3 \text { Nov. } \\
2006\end{array}$ & $\begin{array}{l}\text { There are a dozen others - black and white - } \\
\text { who are talking publicly about their faith. Their } \\
\text { religious rhetoric almost certainly makes the } \\
\text { most secular Democrats wince, but they will be } \\
\text { forgiven if they win. Something is happening in } \\
\text { the party. }\end{array}$ \\
\hline $\begin{array}{l}1 \text { Nov. } \\
2004\end{array}$ & $\begin{array}{l}\text { And, at least in the edited version released by } \\
\text { the Arabic TV channel al-Jazeera, it avoided } \\
\text { religious rhetoric. }\end{array}$ \\
\hline $\begin{array}{l}15 \text { Jan } \\
2008\end{array}$ & $\begin{array}{l}\text { We look at the use of religious rhetoric in the } \\
\text { political arena. }\end{array}$ \\
\hline $\begin{array}{l}19 \text { Oct. } \\
2017\end{array}$ & $\begin{array}{l}\text { To make matters worse, his party appointed } \\
\text { a controversial Hindu religious leader known } \\
\text { for anti-Muslim rhetoric to run the political } \\
\text { bellwether state of Uttar Pradesh, where the } \\
\text { BJP won a decisive mandate in March. }\end{array}$ \\
\hline $\begin{array}{l}27 \text { sep } \\
2003\end{array}$ & $\begin{array}{l}\text { But the group had the unique distinction of } \\
\text { producing some of the finest public speakers, } \\
\text { offering a rare blend of religious rhetoric with a }\end{array}$ \\
\hline
\end{tabular}




\begin{tabular}{|c|c|}
\hline & nchant for the oriental literary tradition. \\
\hline $\begin{array}{l}15 \text { Mar. } \\
2008\end{array}$ & $\begin{array}{l}\text { "But there are cultural, criminal and political } \\
\text { issues that need to be discussed and it is } \\
\text { important that we do not just hide behind } \\
\text { political rhetoric but actually engage and } \\
\text { develop constructive ways to tackle them. }\end{array}$ \\
\hline $\begin{array}{l}7 \text { Sep. } \\
2009\end{array}$ & $\begin{array}{l}\text { Some of their activities raised troubling } \\
\text { questions about political-religious influence in } \\
\text { the military. } \\
\text { Gal Einav, a non-religious soldier, said there } \\
\text { was wall-to-wall religious rhetoric in the base, } \\
\text { the barracks and on the battlefield. } \\
\text { As soon as soldiers signed for their rifles, he } \\
\text { said, they were given a book of psalms. }\end{array}$ \\
\hline $\begin{array}{l}23 \text { May } \\
2006\end{array}$ & $\begin{array}{l}\text { Some speakers, of course, display considerable } \\
\text { native wit and a sense of natural vitality; others } \\
\text { display a wording heavily influenced by } \\
\text { religious rhetoric and ideology. }\end{array}$ \\
\hline $\begin{array}{l}20 \text { Jun } \\
2008\end{array}$ & $\begin{array}{l}\text { They are relying both on their candidate's } \\
\text { comfortable use of religious rhetoric and the } \\
\text { efforts of their well-developed Christian } \\
\text { outreach team, created, in part, to counter one } \\
\text { of the Democrats' long-standing problems - } \\
\text { talking about religion. }\end{array}$ \\
\hline $\begin{array}{l}9 \text { Jan } \\
2010\end{array}$ & $\begin{array}{l}\text { He argues that a video released in October } 2004 \\
\text { - just days before the presidential election - } \\
\text { lacks the religious rhetoric contained in } \\
\text { previous statements. }\end{array}$ \\
\hline
\end{tabular}




\begin{tabular}{|c|c|}
\hline $\begin{array}{l}15 \mathrm{Jul} \\
2009\end{array}$ & $\begin{array}{l}\text { A number of soldiers said they were } \\
\text { uncomfortable with the use of religious rhetoric } \\
\text { by rabbis given access to troops during the } \\
\text { operation. }\end{array}$ \\
\hline $\begin{array}{l}6 \text { Feb } \\
2005\end{array}$ & $\begin{array}{l}\text { This is where all of us came from. That's } \\
\text { science, not religious rhetoric. }\end{array}$ \\
\hline $\begin{array}{l}18 \text { Mars } \\
2017\end{array}$ & $\begin{array}{l}\text { India's governing party has chosen a } \\
\text { controversial Hindu religious leader known for } \\
\text { anti-Muslim rhetoric as the next chief minister } \\
\text { of Uttar Pradesh, the country's most populous } \\
\text { state. }\end{array}$ \\
\hline $\begin{array}{l}24 \text { May } \\
2019\end{array}$ & $\begin{array}{l}\text { Wole Soyinka examines the power of political } \\
\text { and religious rhetoric in his third lecture. He } \\
\text { asks what turns the mantra of faith in one } \\
\text { religion into a summons of death in another? }\end{array}$ \\
\hline $\begin{array}{l}24 \text { May } \\
2019\end{array}$ & $\begin{array}{l}\text { A combination of nationalist rhetoric, subtle } \\
\text { religious polarisation and a slew of welfare } \\
\text { programmes helped Mr Modi to coast to a } \\
\text { second successive win. }\end{array}$ \\
\hline $\begin{array}{l}21 \mathrm{Feb} \\
2017\end{array}$ & $\begin{array}{l}\text { The international community expends great } \\
\text { efforts tackling the 'ideology' of groups such as } \\
\text { ISIS, focusing on the religious rhetoric they } \\
\text { produce, yet completely ignoring the material } \\
\text { circumstances in which they thrive. }\end{array}$ \\
\hline $\begin{array}{l}23 \text { May } \\
2019\end{array}$ & $\begin{array}{l}\text { Pascale Harter presents insights from Gabriel } \\
\text { Gatehouse (tracing the roots of lethal clashes in } \\
\text { Kenya's Tana Delta) and Steve Rosenberg } \\
\text { (noticing increasingly Islamic rhetoric and } \\
\text { imagery in Grozny). }\end{array}$ \\
\hline
\end{tabular}




\section{2- Religious discourse}

\begin{tabular}{|c|l|}
\hline 5 Feb 2015 & $\begin{array}{l}\text { Islamic State: Mid-East press urges } \\
\text { Islamic discourse reform }\end{array}$ \\
\hline 5 Feb 2015 & $\begin{array}{l}\text { A call to renew Islam's religious } \\
\text { discourse has been gaining momentum } \\
\text { in Middle Eastern press in the wake of } \\
\text { the brutal killing of a captured } \\
\text { Jordanian pilot by Islamic State (IS) } \\
\text { militants. }\end{array}$ \\
\hline 5 Feb 2015 & $\begin{array}{l}\text { "The incident reveals psychological } \\
\text { disorder and a misunderstanding of } \\
\text { Islam and requires quick action to } \\
\text { renew religious discourse," Egypt's } \\
\text { state-run Al-Ahramnewspaper says in } \\
\text { a front-page editorial. }\end{array}$ \\
\hline 5 Feb 2015 & $\begin{array}{l}\text { "Military and intelligence wars are } \\
\text { inevitable, but this is not enough. } \\
\text { Renewing religious discourse and } \\
\text { dotting the i's and crossing the t's are } \\
\text { required to stop the brainwashing } \\
\text { going on with the participation of } \\
\text { official and non-official institutions," } \\
\text { the paper says. }\end{array}$ \\
\hline $\begin{array}{l}\text { Although the message was directed at } \\
\text { the French and Nigerian presidents, it } \\
\text { was delivered in Arabic, and contained } \\
\text { many references to jihad and religious }\end{array}$ \\
\hline Feb
\end{tabular}




\begin{tabular}{|c|c|}
\hline & $\begin{array}{l}\text { discourse, with such words as infidels, } \\
\text { brothers, sisters and slaughter. }\end{array}$ \\
\hline $17 \mathrm{Jul} 2015$ & $\begin{array}{l}\text { Some Islamic clerics around the world } \\
\text { have used Ramadan as a chance to } \\
\text { reflect publicly on how to reform the } \\
\text { religious discourse within Islam to } \\
\text { keep up with the challenges of } 21 \mathrm{st} \\
\text { Century life, and to oppose extremism. }\end{array}$ \\
\hline 31 Jan 2014 & $\begin{array}{l}\text { He thinks that many people in the } \\
\text { country could be easily manipulated } \\
\text { through religious discourse, due to } \\
\text { high rates of illiteracy. }\end{array}$ \\
\hline 17 Mar 2004 & $\begin{array}{l}\text { Many commentators in the West have } \\
\text { blamed religious discourse in the } \\
\text { Kingdom and its educational system } \\
\text { for laying the ground for extremism. }\end{array}$ \\
\hline 3 Jul 2014 & $\begin{array}{l}\text { He has stressed that Egypt is } \\
\text { committed to "correcting the religious } \\
\text { discourse" and freeing it from } \\
\text { extremism. }\end{array}$ \\
\hline 15 May 2013 & $\begin{array}{l}\text { Many secular Tunisians attribute the } \\
\text { rise in radical Islam to the religious } \\
\text { discourse of some Islamist preachers } \\
\text { known as Salafists, who adopt a strict } \\
\text { interpretation of their religion. }\end{array}$ \\
\hline 30 Oct 2014 & $\begin{array}{l}\text { Saudi Arabia's Al-Watan newspaper } \\
\text { says "the dream of political Islam is } \\
\text { eroding". Columnist Mazin al-Iliwi } \\
\text { says public awareness has turned away }\end{array}$ \\
\hline
\end{tabular}




\begin{tabular}{|c|c|}
\hline & $\begin{array}{l}\text { from "religious and ideological } \\
\text { discourse... As a result the } \\
\text { Brotherhood in Tunisia has failed to } \\
\text { seize power like Egypt's } \\
\text { Brotherhood." }\end{array}$ \\
\hline 30 Oct 2000 & $\begin{array}{l}\text { Party policy is set by its Council of } \\
\text { Torah Sages, which the rabbi } \\
\text { dominates. It is a world of apocalyptic } \\
\text { religious discourse where decisions } \\
\text { belong to God and those who interpret } \\
\text { God's law. }\end{array}$ \\
\hline 4 Jan 2002 & $\begin{array}{l}\text { However he argues that Arabs need to } \\
\text { examine their affairs with honesty, and } \\
\text { come up with long-overdue reforms of } \\
\text { education and religious discourse. }\end{array}$ \\
\hline 3 Sep 1999 & $\begin{array}{l}\text { Mr Attum says the ban will also be } \\
\text { lifted on Egyptian author Hamid Abu } \\
\text { Zayd, whose book "Criticism of } \\
\text { Religious Discourse" led to him being } \\
\text { accused of apostasy. }\end{array}$ \\
\hline 30 Oct 2000 & $\begin{array}{l}\text { Party policy is set by its Council of } \\
\text { Torah Sages, which the rabbi } \\
\text { dominates. It is a world of apocalyptic } \\
\text { religious discourse where decisions } \\
\text { belong to God and those who interpret } \\
\text { God's law. }\end{array}$ \\
\hline 31 Jan 2006 & $\begin{array}{l}\text { It is not debate, it is not strong } \\
\text { language used in religious discourse, } \\
\text { or even ridicule or theatre. }\end{array}$ \\
\hline
\end{tabular}




\begin{tabular}{|c|c|}
\hline & $\begin{array}{l}\text { It is where people set out with the } \\
\text { intention of stirring up hatred at } \\
\text { people because of their religious } \\
\text { beliefs - that has no place in a modern } \\
\text { civilised society. }\end{array}$ \\
\hline 17 Oct 2017 & $\begin{array}{l}\text { "Violent extremism in IS and the } \\
\text { salafist jihadist groups is justified, } \\
\text { indeed blessed, in Islamic law text } \\
\text { relied on by IS and the extremis } \\
\text { groups. It's a crisis of religious } \\
\text { discourse, not of a barbaric group } \\
\text { Breaking up the religious discourse } \\
\text { and setting it on the right course is } \\
\text { more important by far than } \\
\text { suppressing the extremist groups } \\
\text { militarily." }\end{array}$ \\
\hline $15 \mathrm{Jul} 2009$ & $\begin{array}{l}\text { Testimony } 15 \text { [describing a talk by a } \\
\text { military rabbi]: "Lots of pathos, the } \\
\text { kind of religious discourse I'm a bi } \\
\text { familiar with: war of choice, holy wat } \\
\text { - differing rules. }\end{array}$ \\
\hline 13 Sep 1999 & $\begin{array}{l}\text { The committee has also been a strong } \\
\text { influence on the direction of Sikh } \\
\text { religious and political discourse. }\end{array}$ \\
\hline 5 Jul 2007 & $\begin{array}{l}\text { "I don't watch any religious channe } \\
\text { because where is the time? I go to } \\
\text { temples every now and then and my } \\
\text { daughter also attends religious } \\
\text { discourses but that's as and when we }\end{array}$ \\
\hline
\end{tabular}




\begin{tabular}{|c|c|}
\hline & can manage. \\
\hline 25 Oct 2015 & $\begin{array}{l}\text { Immediately a new word entered the } \\
\text { public discourse - Islamophobia. }\end{array}$ \\
\hline 12 Oct 2001 & $\begin{array}{l}\text { However he represents a strain, a } \\
\text { strain that has grown more and more } \\
\text { virulent, that has taken over religious } \\
\text { discourse in large parts of the Muslim } \\
\text { world, and by the way, that has it's } \\
\text { origin in Arab nationalist secular } \\
\text { categories like anti-imperialist and } \\
\text { anti-Zionism. }\end{array}$ \\
\hline 22 Jun 2014 & $\begin{array}{l}\text { On Tuesday, in Henry The Scholar, Dr } \\
\text { Steven Gunn from Merton College, } \\
\text { Oxford, shows that Henry was one of } \\
\text { the most educated monarchs, speaking } \\
\text { fluent Latin and being well versed in } \\
\text { poetry, music and religious discourse. }\end{array}$ \\
\hline 17 Jan 2007 & $\begin{array}{l}\text { "We have seen the Mela, we go and } \\
\text { hear the religious discourses given by } \\
\text { holy men," says Khadse. }\end{array}$ \\
\hline 16 Sep 2010 & $\begin{array}{l}\text { In his homily, the Pope warned against } \\
\text { people who seek "to exclude religious } \\
\text { belief from public discourse". }\end{array}$ \\
\hline 5 May 2011 & $\begin{array}{l}\text { No-one today can dominate religious } \\
\text { discourse, or stand alone as an } \\
\text { individual, a fundraiser, a sheikh, or an } \\
\text { underground leader in a cave or } \\
\text { palace, as easily as he was able to. }\end{array}$ \\
\hline
\end{tabular}


"Religious rhetoric" was detected in twenty-one stories, whereas "religious discourse" appeared in twentyfive ones. In the Arabic version الخطاب الديني appeared 158 times. Comparing the two corpora of "religious rhetoric" and "religious discourse" on the BBC shows that 'rhetoric' is preferred when there is a political or an election campaign or an attempt to incite the masses to do something by exploiting their religious feelings. In other words, it is used in appellative contexts, whereas 'discourse' is used when talking about revising the processes of teaching and understanding of the basics of religion. Thus, a corpus-based approach to translation makes it a point at which linguistics, cultural studies and modern technologies overlap.

A last example is the rendering of the phrase "State of Union Address" into Arabic. On Feb. 6/2019, the BBC TV newsreader said خطاب حالة الاتحاد. On the next day, another newsreader used خطاب حالة الأمـة. In other places, like Wikipediaxii for example, it is rendered as خطاب حالة الدولة. The three renderings seem acceptable, but there is a need for a standardized rendering for such expressions, hence comes the importance of exerting more efforts towards formulating a media translation theory. Careful corpora analysis must be an essential procedure in such a theory to reach standardization or uniformity of basic terminology in the field of media, especially as far as news articles are concerned, because extracting evidence from a corpus is more authentic than getting it from only one or two examples. Besides, corpus-based analysis not only benefits 
communication at the translation level, but also develops other aspects of language:

At the core of corpus-based pedagogy were the design and navigation of corpora created not only as sources for the retrieval of translation equivalents or as aids for improving the quality and efficiency of the final translation product, but also as repositories of data used to better understand translation processes and language behavior (Alet Kruger, et al, 2011: 20).

\section{Towards Formulating a Media Translation Theory:}

A comprehensive media translation theory should depend on dimensions like the situation in which translation is produced, translator competence, text type, text function, target cultural expectations, end user competence, etc. The theory needs to be flexible and precise at the same time. The problem with media translation is that function in the ST may differ from function of TT. In this case, there is not equivalence of function. When function is not equivalent, the TT is no longer a translation but may be defined as a version of the ST. Skopos theory may be considered a perfect model for assessing the quality of a translation because it evaluates whether the desired function of the translation has been fulfilled or not. Such a theory is also supposed to bridge the gap between linguistics and cultural studies.

Fairclough raises some important questions about different voices within the text: How are social actors represented (activated/passivated, personal/impersonal)? Does the translator mark the authorship of face-threating 
remarks? What value assumptions are made? What is the orientation to difference in the text (an openness to and acceptance of difference)? an accentuation of difference? (Fairclough, 2003:193) The answer to these questions must be the same in both the translation and the ST. This helps the translator produce a precise translation of register: for ظروف الحياة example, can we render the everyday expression as "stress", although they belong to different registers? Issues of identity and power should be reflected in translation. For example, if the doctor uses a colloquial term to reduce the distance between him and the patient, the interpreter must creatively reflect this in the translation for the satisfaction and good treatment of the patient.

Available media corpora would help researchers formulate a comprehensive media translation theory that addresses all aspects in the field whether translational, translatorial or pedagogical. Observation of texts will hopefully help induce/infer a theory. For building such a corpus, the Translational English Corpus (TEC) xiii of the University of Manchester would be a master reference. It consists of four subcorpora: fiction, biography, news and inflight magazines. Thus, TEC and similar corpora are good examples that might inspire the setting up of a media corpus to be a reference for translators in the course of their training and work, thereby work is supposed to be more professional by carrying out searches and statistical analysis that help take the correct and evidenced decision. Different kinds of mistakes could be extracted from the corpus and calculated to 
be discussed from a quantitative and a qualitative point of view.

\section{Conclusion:}

Analyses of texts from the $\mathrm{BBC}$ along different periods of time, within more than three years, prove that the English version is the source from which Arabic translations/versions branch off, even if the story is about a local issue in the Arab world: for example, the twenty four words above, in the passage on war in Syria and Iraq, are condensed into only seventeen words. Collocational problems and ambiguity in the Arabic renderings also prove that the English texts are always the source text. Sometimes, there is intentional or unintentional manipulation in the TT that changes relations of power and ideology implied in the ST. As far as other languages on the BBC are concerned, this needs further studies. The following conclusions and recommendations, on merits and demerits of the BBC Arabic and English websites, might be of help (i.e. guidelines) to the translators of news stories:

The merit of texts on the BBC Arabic and English websites is that one may rarely find patterns that are distinctive of translated texts as opposed to texts produced in a non-translational environment; texts seem natural and not alien. This supports the idea of standardizing the BBC model and techniques of translation, as far as style is concerned. Famous media institutions should open translation academies to train translators on real-life activities that would lead them towards proficiency and competitiveness; media organizations establish new sections for languages other than 
English everyday: for example, the Independent Journal has launched an Arabic website on Jan. 24/2019. News service has so many sources and every institution should develop itself to achieve success, competitiveness and attract new audience via applying modern and authentic translation strategies.

Use of the BBC parallel corpora in the study shows that they have a great benefit to translators and students of translation. There is an urgent need for building Arabic translational corpora at a regional level. Such corpora are to be used with other linguistic and cultural tools within the framework of a multidisciplinary approach to get the best results for any issue in translation studies. Application of Fairclough's method together with evidence from various corpora help in producing logical analysis and acceptable results.

Translational product on the BBC is acceptable because Chesterman's three dimensions of causation are carefully considered as implied from the examples. To keep this good level, the metacognition of media translators needs more study to be organized in a way that saves the translator's time and help produce best renderings. Organizing the cognitive steps of the translation process in a systematic way would have good results. More crystallization of the concepts of language and culture will contribute to the development of traditional approaches in translation studies. In so doing, new and more specific translation theories will be developed: a media translation theory, a medical translation theory, a poetry translation theory, etc. 


\section{Endnotes}

${ }^{\mathrm{i}}$ Dependent variable, i.e. the core concept we are trying to assess in our research question.

ii Independent variable, i.e. things that we manipulate in order to see what the effect is on our dependent variable.

iii If the answer is: there is no influence of time pressure on quality of translation, so we have a null hypothesis (Gabriela Saldanha \& Sharon O'Brien: 25).

iv Characterizing a variety of language is a job that may be done via CL.

v Inducing/inferring explanations, generalizations or theories from specific observations.

"من أهم مواصفات العنوان هي أن يكون واضحا وجاذبا للمتابعة ومستحثا

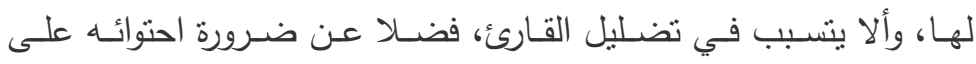

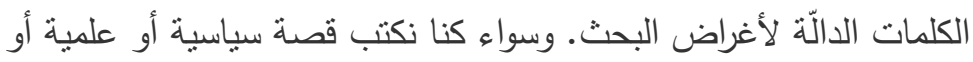

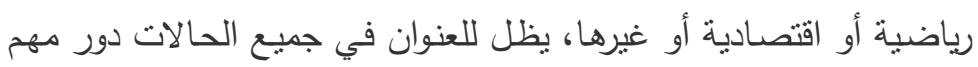

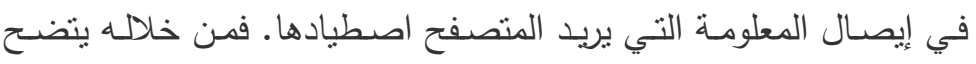

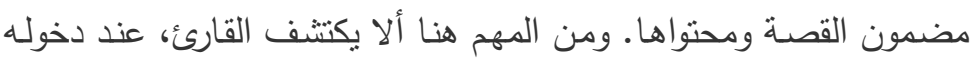

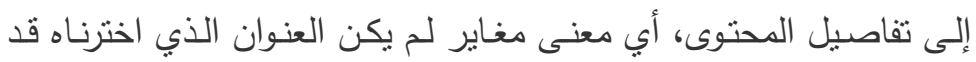

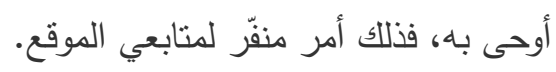

https://www.bbc.co.uk/academy/ar/articles/art201307021

12133955

vii

Isis defeated, US-backed Syrian Democratic Forces

announce

Kurdish-led group says last of militants cleared from stronghold of Baghuz

After almost five years, the battle to dismantle Islamic State's brutal "caliphate" has ended with an announcement from US-backed 
forces that the militants have been driven out of their last stronghold of Baghuz.

Isis had held out for months against the Syrian Democratic Forces (SDF) in the small oasis town on the Euphrates river, clinging on to an area of land less than $700 \mathrm{sq}$ metres wide despite fierce coalition bombing. But on Saturday an SDF spokesperson, Mustafa Bali, tweeted that the town had been liberated.

"On this unique day we commemorate thousands of martyrs whose efforts made the victory possible," he wrote.

One of the group's infamous black flags was ripped apart and trampled underfoot by SDF troops on the riverbank, also littered with shrapnel and discarded suicide belts. Kurdish pop music blasted from armoured cars and young male and female recruits danced and fired AK-47s in the air in celebration.

"Three days ago we clutched our weapons, trying to break forward even a few metres," a fighter called Rami told AFP.

"But now we've finished with Isis and its black banner and we've hoisted our own instead."

The elimination of the caliphate is a significant symbolic victory against Isis, which at the height of its power held more than 8 million people hostage to its bloody interpretation of Islamic law in a swath of territory across Syriaand Iraq that was roughly the size of the UK.

Theresa May praised the "extraordinary courage" of the UK armed forces and their allies against the group, also known as Daesh.

(The Guardian: 23/3/2019)

https://www.theguardian.com/world/2019/mar/23/isis-defeated-usbacked-syrian-democratic-forces-announce

vii Longman Dictionary of Contemporary English. 
ix http://www.bbc.com/arabic/world-40396572 (June 25/2017)

$\mathrm{x}$ https://theinformant.cl/trump-travel-ban-comes-into-effect-for-six-countries/ (June 30, 2017)

${ }^{x i}$ http://www.bbc.com/arabic/world-40454703 (June 30, 2017) xii

https://ar.wikipedia.org/wiki/\%D8\%AE\%D8\%B7\%D8\%A7\%D8\%A8_\%D8\%AD\%D 8\%A7\%D9\%84\%D8\%A9_\%D8\%A7\%D9\%84\%D8\%A7\%D8\%AA\%D8\%AD\%D8 $\% \mathrm{~A} 7 \% \mathrm{D} 8 \% \mathrm{AF}$

xiii https://www.alc.manchester.ac.uk/translation-and-interculturalstudies/research/projects/translational-english-corpus-tec/ 


\section{English Works Cited}

Al-Azzam, B., Al-Ahaydib, M., Al-Huqail.E. (2015).

Cultural problems in the translation of the Qur'an.

International Journal of Applied Linguistics and Translation, 1(2), 28-34. doi: 10.11648/j.ijalt.20150102.12

Baker, M. (2006). Translation and Conflict: A Narrative Account. New York: Routledge.

Bowker, L. and Pearson, J. (2002). Working with

Specialized Language: A Practical Guide to Using

Corpora. London \& New York: Routledge.

Chesterman, A. (2017). 'A Causal Model for Translation Studies. In Maeve Olohan (ed.), Intercultural Faultlines: Research Models in Translation Studies I - Textual and Cognitive Aspects (15-28). Manchester: St. Jerome.

Cowan, J. M. (1980). Hans Wehr A Dictionary of Modern Written Arabic. Beirut: Librairie Du Liban.

Crystal, D. (1992). A Dictionary of Linguistics and Phonetics. London: Blackwell.

Dickins, J., Hervey, S. and Highins, I. (2002). Thinking Arabic Translation: A Course in Translation Method: Arabic to English. London and New York: Routledge. Fairclough, N. (2003). Analyzing Discourse (Textual Analysis for Social Work). New York: Routledge.

Fairclough, N. (2013). Critical Discourse Analysis (the critical study of language). New York: Routledge. 
Gadsby, A. ed. (2017). Longman Dictionary of Contemporary English (LDCE). Essex: Longman UK Limited.

Gee, J. P. and Handford, M. (2011). The Routledge Handbook of Discourse Analysis. New York: Routledge.

Gillham, B. (2000). Case Study Research Methods, London $\&$ New York: Continuum.

Hanna, S. (2016). Bourdieu in Translation Studies: the Socio-cultural Dynamics of Shakespeare Translation in Egypt. London: Taylor \& Francis

Hatim, B. and I. Mason (1993). Discourse and the Translator. Singapore: Longman.

House, J. (2011). Using Translation and Parallel Text Corpora to Investigate the Influence of Global English on Textual Norms in Other Languages. In A. Kruger, K. Wallmach and J. Munday (Eds.), CorpusBased Translation Studies, Research and Applications (p.p.187-208). Chennai, India: Continuum.

Ji, Meng and Oakes, M. P. (2013). 'A Corpus Study of Early English Translations of Cao Xueqin's Hongloumeng'. In Michael P. Oakes and Meng Ji (Eds.), Quantitative Methods in Corpus-Based Translation Studies (p.p. 177-208). Amsterdam \& Philadelphia: John Benjamins.

Katan, D. and F. Straniero-Sergio (2014). "Submerged Ideologies in Media Interpreting". In María Calzada 
Pérez (Ed.). Apropos of Ideology (p.p. 131-144). New York: Routledge.

Kilgarriff, A. (2006). Collocationality (and how to measure

it). In E. Corino, C. Marello, \& C. Onesti (Eds.), Proceedings of the 12th EURALEX International Congress (997-1004). Italy, Torino: Edizioni dell'Orso. Retrieved from

https://euralex.org/publications/collocationality-and-

how-to-measure-it/ (accessed 30 August 2020)

Kruger, A., Wallmach, K., \& Munday, J. (2011). CorpusBased Translation Studies, Research and Applications. Continuum: Chennai, India.

Lane, E. W. (1997). An Arabic-English Lexicon. Lebanon, Beirut: Librairie du Liban.

Munday, J. (2011). Looming Large: A Cross-Linguistic Analysis of Semantic Prosodies in Comparable Reference Corpora. In Alet Kruger, Kim Wallmach and Jeremy Munday (Eds.), Corpus-Based Translation Studies, Research and Applications (p.p.169-186). Chennai, India: Continuum.

Munday, J. (2016). Introducing Translation Studies. New York: Routledge.

O'Halloran, K. (2011). Critical Discourse Analysis. In J. Simpson (ed.), The Routledge Handbook of Applied Linguistics (p.p. 445-459). New York: Routledge.

Okasha, T. (2014). Rendering Preposition in the Holy Qur'an. An unpublished PhD thesis. Egypt: Minia University. 
Olohan, M. (2017). Intercultural Faultines: Research Models in Translation Studies I - Textual and Cognitive Aspects. Manchester: St. Jerome.

Pearson, J. (2003). Using Parallel Texts in the Translator Training Environment. In Federico Zanettin, Silvia Bernardini, and Dominic Stewart (Eds.), Corpora in translator education (p.p.15-24). Manchester, United Kingdom: St. Jerome Publishing.

Pérez, M. C. (2014). Apropos of Ideology. New York: Routledge.

Saldanha, G. and O'Brien, S. (2014). Research Methodologies in Translation Studies. London: Routledge.

Simpson, J. (2011). The Routledge Handbook of Applied Linguistics. New York: Routledge.

Schleppegrell, M. J. (2011) Systemic functional linguistics. In James Paul Gee and Michael Handford (eds.), The Routledge Handbook of Discourse Analysis (p.p. 2134). New York: Routledge.

Tawfiq, Khaled. (2013). "Translation of Ideology or Ideology of Translation: Towards a Feminist Model of Translation". Logos, 9: 39-66.

Tawfiq, Khaled. (2014). "A Linguistic Analysis of the Difficulties Faced by Professional Translators in Rendering Problematic Arabic Headlines: Implications for Designers of Newspaper Translation Courses". Faculty of Arts Journal, Cairo University, 74: 137-198, July. 2014. 


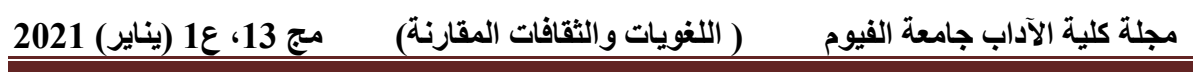

\section{Arabic Works Cited}

خالد توفيق. قواعد الترجمة الصحفية. القاهرة: هلا للنشر والتوزيع (2017)

(Adaptation or Loss in News Translation...) Dr. Taher Okasha 


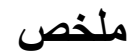

إن هذا البحث المعنون "ترجمة الأخبار بين التحوير والفقدان" يعالج إثكالية ترجمة

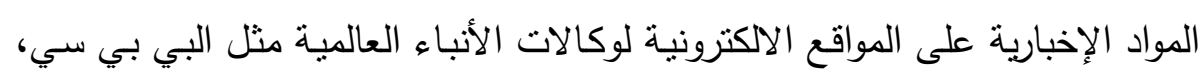
حيث يعرض الباحث عينات من الأخبار المختلفة، معتمداً على منهج بيني لتحليلها من منظور لغوي وثقافي. ومن الأدوات المستخدمة في هذا التحليل طريقة فيركلف لتحليـل النصـوص، واليـات علم لسـانيات المـدونات، وتحليـل الخطـاب، مـع مناقثــة الظروف التي ينتج فيها المترجم عمله: كمعيار الوقت المتاح وسياسـات المؤسسـة والجمهور المستهدف، وكذللك الأبعـاد المتعـدة التي ينتج فيهـا الخطـاب، كالبعـد الاجتماعي والتقافي والتاريخي، وغيره من الأمور الكامنة التي تخيم بظلالها على الرسالة التي يحملها النص. وقد بيَّن تحليل العينة المنتقاة على فترات مختلفة أن كافة الأخبار قد تتعرض لعملية تحوير من أجل تيسير الفهم على القارئ. وخلصت الدراسة إلى أن سوق الترجمة في العالم العربي يحتاج إلى مدونات خاصـة لخدمة الترجمة، وحل المشكلات التي تواجـه مترجمي المواد المختلفة على المواقع الإخباريـة، وذلك بالاعتماد على منهج بيني يساعد المترجم على تقديم منتج أفضل.

الكلمـات الدالـة: ترجمـة الأخبـار - نظريـة الترجمـة - لسـانيات المدونات - طريقة فيركلف لتحليل النصوص 